\title{
Garlic (Allium sativum L.) fed to dairy cows does not modify the cheese-making properties of milk but affects the color, texture, and flavor of ripened cheese
}

\author{
Giulia Rossi, ${ }^{*}$ Stefano Schiavon, ${ }^{*}$ Giovanna Lomolino, ${ }^{*}$ Claudio Cipolat-Gotet, $†$ Alberto Simonetto, \\ Giovanni Bittante, ${ }^{*}$ and Franco Tagliapietra*1 \\ *Department of Agronomy, Food, Natural Resources, Animals and Environment (DAFNAE), University of Padua, Viale dell'Università 16, \\ 35020 Legnaro (PD), Italy \\ †Department of Veterinary Science, University of Parma, Via del taglio 10, 43126 Parma, Italy
}

\begin{abstract}
Garlic and garlic components have recently been proposed as ruminal activity modulators to reduce the enteric methane emissions of ruminants, but little is known of their influence on milk coagulation properties, nutrient recovery, cheese yield, and sensorial and rheological characteristics of milk and cheese. The present study assessed the effects of garlic and diallyl sulfide supplements on dry matter intake (DMI), productive performance, milk coagulation properties, cheese yield, milk and cheese sensory profiles, and rheological characteristics. Four dairy cows were fed a total mixed ration either alone (control) or supplemented with 100 or $400 \mathrm{~g} / \mathrm{d}$ of garlic cloves or $2 \mathrm{~g} / \mathrm{d}$ of diallyl sulfide in 4 consecutive experimental periods in a $4 \times 4$ Latin square design. The diallyl sulfide dose was established to provide approximately the same amount of allyl thiosulfinate compounds as $100 \mathrm{~g}$ of fresh garlic cloves. The total mixed ration was composed of 0.29 corn silage, 0.23 corn-barley mixture, 0.17 sunflower-soybean mixture, 0.12 alfalfa hay, 0.12 grass hay, 0.04 sugar beet pulp, and 0.02 other additives, and contained 0.253 starch, 0.130 crude protein, and 0.375 neutral detergent fiber, on a dry matter basis. Each experimental period consisted of $7 \mathrm{~d}$ of transition and $14 \mathrm{~d}$ of treatment. On d 18 and 21 of each period, milk samples (10 L) were collected from each cow for chemical analysis and cheese-making. The organoleptic properties of the milk and 63-d-ripened cheeses were assessed by a panel of 7 trained sensory evaluators. The experimental treatments had no effects on DMI, milk yield, feed efficiency (milk yield/DMI), milk coagulation properties, nutrient recovery, or cheese yield. Garlic-like aroma, taste, and flavor of milk and cheese were significantly influenced
\end{abstract}

Received September 23, 2017.

Accepted November 16, 2017.

${ }^{1}$ Corresponding author: franco.tagliapietra@unipd.it by the treatments, particularly the highest dose of garlic cloves, and we found close exponential relationships between milk and cheese for garlic-like aroma $\left(\mathrm{R}^{2}=\right.$ $0.87)$ and garlic-like flavor $\left(\mathrm{R}^{2}=0.79\right)$. Diallyl sulfide and $400 \mathrm{~g} / \mathrm{d}$ of garlic cloves resulted in lower $\mathrm{pH}$, shear force, and shear work of ripened cheeses compared with the other treatments. Garlic cloves and diallyl sulfide had opposite effects on cheese color indices. We conclude that adding $400 \mathrm{~g} / \mathrm{d}$ of garlic to the feed of lactating dairy cows highly influences the sensory and rheological characteristics of cheese.

Key words: cheese yield, diallyl sulfide, garlic clove, milk coagulation properties, sensory analysis

\section{INTRODUCTION}

Methane produced in the rumen is a potent greenhouse gas, and the Food and Agriculture Organization of the United Nations (Steinfeld et al., 2006) has asserted that $18 \%$ of total anthropogenic greenhouse gases are directly or indirectly related to the livestock industry. Others have estimated that the contribution of ruminants to global warming is more likely on the order of 3\% (Pitesky et al., 2009). However, as methane represents a 2 to $12 \%$ loss of energy in the conversion of feed to animal products, many strategies have been proposed to lower emissions of this gas without impairing rumen fermentation and animal performance (Hristov et al., 2013a,b).

Garlic (Allium sativum L.), and particularly its sulfur compounds, inhibits in vitro methanogenesis (Blanch et al., 2016) and consistently increases the acetate: propionate ratio and butyrate concentration in the rumen fluid (Yang et al., 2007; Klevenhusen et al., 2011). The effect is similar, but not identical, to that of the antibiotic monensin (Calsamiglia et al., 2007), and reflects the antimicrobial and antiprotozoal properties of organosulfur garlic compounds (Reuter et al., 1996). Busquet et al. (2005) suggested that the antimethano- 
genic action mechanism of garlic could be related to direct inhibition of archaea rumen bacteria through inhibition of the 3-hydroxy-3-methyl-glutaryl coenzyme A (HMG-CoA) reductase of its organosulfur compounds. Macheboeuf et al. (2006) reported dose response effects of garlic oil and some sulfur garlic compounds (diallyl sulfide, diallyl disulfide, allicin, and allyl mercaptan) on ruminal fermentation and in vitro methane production. Garlic in various forms (cloves, powder, oil, or pure sulfur compounds) was found to have antiparasitic, anticancer, antioxidant, immunomodulatory, anti-inflammatory, and hypoglycemic activities in ruminants (Kamra et al., 2012).

A few experiments have investigated the effect in vivo of garlic, or its sulfur constituents, on digestion, ruminal fermentation, and milk production and quality in dairy cows (van Zijderveld et al., 2011; Oh et al., 2013; Blanch et al., 2016). There is little data available of the effect of garlic as a feed additive on milk coagulation properties, nutrient recovery, cheese yield, and sensorial and rheological characteristics of milk and cheese. In humans, volatile metabolites of garlic were detected in milk a few hours after ingestion of garlic cloves, and the sensory characteristics of the milk were consistently modified (Scheffler et al., 2016). By analogy, we hypothesize that the sensory characteristics of bovine milk and cheese might also be influenced by adding garlic or its sulfur compounds to the cows' feed.

The current experiment aimed to evaluate the influence of increasing doses of garlic cloves or diallyl sulfide on productive performance, coagulation, and cheesemaking properties of milk, and sensory and rheological characteristics of milk and cheese.

\section{MATERIALS AND METHODS}

\section{Animals, Rations, and Experimental Design}

The project was approved by the University of Padua's Ethical Committee for the Care and Use of Experimental Animals, in accordance with Italian law on the care of research animals. To minimize the use of animals, we adopted a Latin square design and used only one cow per treatment.

Four Holstein-Friesian dairy cows in second parity were housed in individual pens on the University of Padua's experimental farm (Legnaro, Italy). At the start of the experiment, the cows had an average 119 \pm 17 DIM and $30.8 \pm 3.4 \mathrm{~kg} / \mathrm{d}$ of milk yield, and an average BW of $621 \pm 26.1 \mathrm{~kg}$ and BCS of $2.69 \pm 0.32$ on a 5-point scale. The cows were assigned to 4 feeding treatments in a $4 \times 4$ Latin square design. Each experimental period lasted $14 \mathrm{~d}, 7 \mathrm{~d}$ for adaptation and $7 \mathrm{~d}$ for recording and sample collection, and was followed by a 7-d transition period to reduce possible carryover effects. Feeds were distributed to each cow as a lowprotein TMR, the ingredients and nutritional composition of which were in accordance with NRC (2001) and Schiavon et al. (2015) for a milk yield of $30 \mathrm{~kg} / \mathrm{d}$ (Table $1)$. The 4 experimental treatments were a control diet (no supplementation), a supplement of $2 \mathrm{~g} / \mathrm{d}$ of pure (0.97) diallyl sulfide (allyl sulfide, Sigma-Aldrich Chemical, Milan, Italy), and 100 or $400 \mathrm{~g} / \mathrm{d}$ of fresh peeled garlic cloves (cultivar 'Aglio Bianco Polesano'). The garlic supplements were devised to provide approximately 4.35 or $17.39 \mathrm{~g} / \mathrm{kg}$ of DMI, compared with the $10 \mathrm{~g} / \mathrm{kg}$ of DM used by Patra and Saxena (2010) for sheep. The $2 \mathrm{~g} / \mathrm{d}$ of diallyl sulfide corresponded, in terms of total sulfur content, to approximately $100 \mathrm{~g} / \mathrm{d}$ of fresh garlic cloves.

At $0800 \mathrm{~h}$, before TMR distribution, the peeled garlic cloves were weighed and mixed with about $3 \mathrm{~kg}$ of feed in a bowl to ensure they were completely consumed. Similarly, the diallyl sulfide was diluted in $150 \mathrm{~mL}$ of water and sprayed evenly over $3 \mathrm{~kg}$ of feed in a bowl and then distributed to the animal. The TMR was then

Table 1. Ingredients and chemical composition ( $\mathrm{g} / \mathrm{kg}$ of DM unless otherwise noted) of the TMR top-dressed or not with garlic cloves or diallyl sulfide ${ }^{1}$

\begin{tabular}{lcc}
\hline Item & TMR & Garlic cloves \\
\hline Ingredient & 291 & \\
Corn silage & 233 & - \\
Corn-barley based mixture & 173 & - \\
Sunflower-soybean based mixture & 123 & - \\
Alfalfa hay & 120 & - \\
Ryegrass hay & 37 & - \\
Sugar beet pulp & 13 & \\
Mineral and vitamin mixture ${ }^{2}$ & 10 & - \\
Linseed & & \\
Chemical composition & 462 & 744 \\
DM, g/kg as fed & 130 & 192 \\
CP & 34 & 5 \\
Ether extract & 375 & 62 \\
NDF & 219 & 25 \\
ADF & 37 & 3 \\
ADL & 253 & - \\
Starch & 401 & 704 \\
NSC & 60 & 37 \\
Ash & 1.27 & 8.45 \\
Total S, mg/g of DM & & \\
IDialyl & & \\
\hline
\end{tabular}

${ }^{1}$ Diallyl sulfide (Allyl sulfide, 0.97 pure, Sigma-Aldrich Chemical, Milan, Italy), with a stoichiometric S content of $0.281\left(\mathrm{C}_{6} \mathrm{H}_{10} \mathrm{~S}\right)$, was top dressed in dose of 0 or $2 \mathrm{~g} / \mathrm{d}$, where garlic cloves were top-dressed in doses of 0,100 , or $400 \mathrm{~g} / \mathrm{d}$.

${ }^{2}$ Milk H (Tecnozoo, Torreselle di Piombino Dese, Padova, Italy); contained per kilogram: 470,000 IU of vitamin A, 60,000 IU of vitamin $\mathrm{D}_{3}$, $2,000 \mathrm{mg}$ of vitamin $\mathrm{E}, 200 \mathrm{mg}$ of vitamin $\mathrm{B}_{1}, 150 \mathrm{mg}$ of vitamin $\mathrm{B}_{2}$, $100 \mathrm{mg}$ of vitamin $\mathrm{B}_{6}, 0.3 \mathrm{mg}$ of vitamin $\mathrm{B}_{12}, 12,000 \mathrm{mg}$ of niacin, 40 $\mathrm{mg}$ of biotin, $60 \mathrm{mg}$ of calcium (as calcium D-pantothenate), 2,000 $\mathrm{mg}$ of betaine (as betaine hydrochloride), 1,000 $\mathrm{mg}$ of choline chloride, 300 $\mathrm{mg}$ of iron, $150 \mathrm{mg}$ of iodine, $30 \mathrm{mg}$ of cobalt, $300 \mathrm{mg}$ of copper, 2,000 $\mathrm{mg}$ of manganese, $3,000 \mathrm{mg}$ of zinc, and $15 \mathrm{mg}$ of selenium.

${ }^{3}$ Calculated as 1,000 - ether extract - CP - NDF - ash. 
distributed to the cows at about 0900 and 1300 h every day.

\section{Sampling and Controls}

The cows were weighed and assigned a BCS by the same trained technician at the beginning and end of each experimental period (Edmonson et al., 1989). Dry matter intake was calculated from the weight of the TMR distributed daily to each cow and the orts collected during the second experimental week. Samples of the base TMR and orts $(1 \mathrm{~kg})$ were collected on $\mathrm{d}$ 12 and 14 of each experimental period, and pooled by period before analysis. Feed efficiency was computed as the milk yield/DMI ratio.

Cows were milked twice a day, at 0600 and $1700 \mathrm{~h}$, and daily milk yield was recorded during the second experimental week of each period. Milk samples $(50 \mathrm{~mL})$ were collected every day at the morning and evening milkings for analysis of chemical composition, and milk coagulation and curd firming properties. Aliquots of milk produced by each cow $(5 \mathrm{~L})$ were also collected in the morning and evening of $\mathrm{d} 12$ and 14 of each experimental period for cheese making. Milk samples (1 L) for sensory analysis were collected from each cow in the morning and evening of d 12 of each experimental period. The milk samples were immediately sent in sealed bottles to the sensory laboratory for analysis. Other milk samples were collected for the analysis of the milk fatty acid profile to achieve an indirect estimation of the in vivo enteric methane emission, but the results are not given in this paper (Negussie et al., 2017).

\section{Chemical Analyses}

The TMR and garlic cloves used during the trial were analyzed in triplicate according to AOAC International (2003) for DM (method 934.01), CP (method 976.05), ether extract (method 920.29) and ash (method 942.05). Neutral detergent fiber, expressed inclusive of residual ash, was determined with $\alpha$-amylase and sodium sulfite in a neutral detergent solution (Mertens et al., 2002) using an Ankom220 Fiber Analyzer (Ankom Technology Corporation, Macedon, NY). Acid detergent fiber, expressed inclusive of residual ash, and sulfuric acid lignin (ADL) content were determined sequentially after NDF analysis (Robertson and Van Soest, 1981). Starch content was determined after hydrolysis to glucose by liquid chromatography (AOAC International, 2003), and NSC were calculated as 1,000 - ether extract - CP - NDF - ash.

Garlic cloves and TMR samples ( $0.5 \mathrm{~g}$ of DM) were analyzed for their S content. The samples were digested in a microwave (Milestone Srl, Sorisole, Bergamo, Italy) with $7 \mathrm{~mL}$ of superpure $67 \% \mathrm{HNO}_{3}$ and $2 \mathrm{~mL}$ of $30 \%$ $\mathrm{H}_{2} \mathrm{O}_{2}$. The operating conditions were temperature increase from 25 to $200^{\circ} \mathrm{C}$ in $15 \mathrm{~min}$, held for $18 \mathrm{~min}$, and temperature decrease from 200 to $35^{\circ} \mathrm{C}$ in 25 min. After cooling to room temperature, the dissolved sample was diluted with ultrapure water to a final volume of $50.0 \mathrm{~mL}$. Sulfur was determined using an Arcos EOP inductively coupled plasma-optical emission spectrometer (Spectro Analytical Instruments $\mathrm{GmbH}$, Kleve, Germany).

Individual morning and evening milk subsamples, preserved with 2-bromo-2-nitro-1,3-propanediol, were separately subjected to infrared analysis for fat, protein, casein, lactose, and total solids contents using a Milko-Scan (FT2, Foss Electric A/S, Hillerød, Denmark). Somatic cell counts were obtained with a Fossomatic (FC automatic counter, Foss Electric A/S) and log-transformed using the following equation: SCS $=3+\ln _{2}\left(\mathrm{SCC} \times 10^{-5}\right)$, as reported by Ali and Shook (1980). Milk pH was measured using a Crison Basic 25 electrode (Crison, Barcelona, Spain). Milk protein fractions were analyzed by reverse-phase HPLC, following Maurmayr et al. (2013).

\section{Milk Coagulation Properties}

Traditional milk coagulation properties (MCP) were measured with a Formagraph (Foss Electric A/S) and expressed in terms of rennet coagulation time (RCT, min), curd-firming time $\left(\mathbf{k}_{\mathbf{2 0}}, \mathbf{m i n}\right)$, and curd firmness 30 min after rennet addition $\left(\mathbf{a}_{\mathbf{3 0}}, \mathbf{m m}\right)$, according to the method proposed by McMahon and Brown (1982). Because, on average, the milk samples coagulated very late, curd firmness was also recorded 45 and $60 \mathrm{~min}$ after rennet addition $\left(\mathbf{a}_{45}, \mathbf{a}_{60}, \mathrm{~mm}\right)$. Given the shortcomings of traditional MCP demonstrated by Bittante (2011), all 240 Formagraph measures (one every $15 \mathrm{~s}$ for $60 \mathrm{~min}$ ) taken from each milk sample were retrieved from the instrument and modeled using the following equation:

$$
\mathrm{CF}_{\mathrm{t}}=\mathrm{CF}_{\mathrm{P}} \times\left[1-e^{-\mathrm{k}_{\mathrm{CF}} \times\left(\mathrm{t}-\mathrm{RCT}_{\mathrm{eq}}\right)}\right]
$$

where $\mathrm{CF}_{\mathrm{t}}$ is curd firmness at time $\mathrm{t}(\mathrm{mm}) ; \mathrm{CF}_{\mathrm{P}}$ is the asymptotical potential value of $\mathrm{CF}$ at an infinite time $(\mathrm{mm}) ; \mathrm{k}_{\mathrm{CF}}$ is the curd-firming rate constant (\%/min); and $\mathrm{RCT}_{\text {eq }}$ is the rennet coagulation time estimated from all the information recorded. The parameter $\mathrm{CF}_{\mathrm{P}}$ is conceptually independent from test duration and is not intrinsically dependent on RCT (unlike $\mathrm{a}_{30}$ ). The parameter $\mathrm{k}_{\mathrm{CF}}$ describes the shape of the curve from milk gelation to infinity and is conceptually different 
from $\mathrm{k}_{20}$, as it is independent of $\mathrm{CF}_{\mathrm{P}}$, but uses all the available information.

\section{Cheese Making}

The morning and evening milk samples collected from each cow were pooled by day. Two cheese-making sessions were carried out in each period, giving a total of 32 cheese wheels produced in this experiment ( 8 per period). Cheeses from the 4 treatments were manufactured (Cattani et al., 2014) simultaneously in 4 small-scale experimental vats, without any preliminary heat treatment or skimming of milk samples. Briefly, milk from each cow was poured into a 10-L vat (Pierre Guérin Technologies, Mauze, France) and heated to $35^{\circ} \mathrm{C}$ by water circulation. The starter culture Streptococcus thermophilus (CSL Starter Cultures, Lodi, Italy) was added to facilitate milk acidification. After $20 \mathrm{~min}$, $2.5 \mathrm{~mL}$ of liquid rennet (Naturen Standard 215, Hansen, Pacovis Amrein AG, Bern, Switzerland) diluted in $40 \mathrm{~mL}$ of distilled water was added to the milk. After milk gelation, the curd was cut in 4 consecutive steps (at $3,4.15,5.30$, and 10.45 min after gelation; each step $15 \mathrm{~s})$ to obtain curd cubes of about $0.5 \mathrm{~cm}^{3}$, and then cooked to $45^{\circ} \mathrm{C}$. Following the syneresis phase $(20 \mathrm{~min})$, each individual curd was extracted from the vat, put into a cheese mold, pressed, and immersed in a brine solution $(20 \% \mathrm{NaCl})$ for $24 \mathrm{~h}$. Cheese yields and nutrient recoveries were computed for fresh curd according to Cipolat-Gotet et al. (2013). Finally, the cheeses were stored for $63 \mathrm{~d}$ at $15^{\circ} \mathrm{C}$ and $85 \%$ relative humidity and weighed.

\section{Sensory Analysis}

Sensory analyses were carried out by a panel of 7 trained evaluators with experience of the products in a testing room designed in accordance with ISO 8589 (ISO, 1988) and equipped with individual booths and standard CIE (Commission internationale de l'éclairage) white illumination $\mathrm{D}_{65}$ (Pinho et al., 2004). The panelists were 7 women, $37 \pm 2 \mathrm{yr}$ old, selected on the basis of their ability to identify the 4 basic tastes of sweetness, bitterness, saltiness, and sourness, and the aroma/flavor compounds, including diallyl sulfide and garlic cloves.

The panelists had previously attended 4 training sessions in which commercial fresh whole milk and caciotta cheese ( $50 \mathrm{~d}$ of ripening) were used to familiarize them with the products and in which they discussed the vocabulary (Meilgaard et al., 1991) for the quantitative descriptive analysis of the milk and cheese. During these preliminary sessions, the evaluators agreed upon a list of descriptors for the aroma, taste, and flavor of milk and cheese, as suggested by Pagliarini et al. (1991). Garlic-like aroma and flavor were identified using crushed garlic cloves, fruit flavor was associated with almond and walnut, and grass aroma with green grass. The panel made their sensory assessment of milk in terms of 2 aromas (overall aroma intensity and garlic-like aroma), 3 tastes (sweet, salty, and bitter), and 2 flavors (overall flavor intensity and garlic-like flavor). The descriptors for the cheese samples included 4 aromas (aroma intensity, grass, fruit, garlic), 4 tastes (sweet, salty, sour, bitter), and 2 flavors (flavor intensity and garlic-like flavor). Attributes were scored on a scale of 1 (absence of perception) to 10 (very intense) anchored with standard food references (Lavanchy et al., 1999), which, in the current work, were represented by commercial milk and caciotta cheese.

Four milk evaluation sessions and 4 cheese evaluation sessions were carried out, in conformity with ISO 6658 (ISO, 1985). In each milk testing session, the 4 individual milk samples of the evening and those of the following morning were pooled by cow into 2-L bottles, kept at room temperature, and scored in 2 replications. Ripened cheese samples were prepared according to Bàrcenas et al. (2007), and the wheels were cut into 2 and placed under vacuum. Immediately before the evaluation, cheese samples $(1.5 \mathrm{~cm}$ thick $\times 5 \mathrm{~cm}$ wide $\times 6-8 \mathrm{~cm}$ long) were prepared, representing the whole cheese wheel without the rind. The cheese evaluations were also performed in 2 replications.

All milk and cheese samples, equilibrated at room temperature $\left(21 \pm 1^{\circ} \mathrm{C}\right)$, were identified by random 3 -digit codes and presented to assessors in randomized order (Suzzi et al., 2015). Water and breadsticks were provided to rinse the mouth after each taste.

\section{Rheological Analysis}

The following analyses were performed on all the cheese wheels after $63 \mathrm{~d}$ of ripening. The $\mathrm{pH}$ was measured in triplicate with a $\mathrm{pH}$ meter (Hach Lange, Crison Instruments Sa, Carpi, Italy) equipped with a specific electrode (cat. 5053T, Crison Instruments s.a.).

Color was assessed on cheese cylinders $1 \mathrm{~cm}$ in diameter and $1 \mathrm{~cm}$ long after exposure to the air $(1 \mathrm{~h}$, $21 \pm 1^{\circ} \mathrm{C}$ ) from 5 consecutive sites from the rind to the center by a spectrophotometer (CM-600, Minolta Corp., Ramsey, NJ) set on illuminant D65 (standard daylight), and with a $10^{\circ}$ observer. Data were expressed according to the CIE L*a*b* colorimetric system (CIE, 1986), where $L^{*}$ represents reflection $(0=$ black, $100=$ white) and $a^{*}$ and $b^{*}$ have no specific numerical limits: $a^{*}$ ranges from green (negative values) to red (positive values), and $b^{*}$ ranges from blue (negative values) to yellow (positive values). 
Table 2. Productive performance and milk quality of cows fed TMR supplemented or not with diallyl sulfide ${ }^{1}(2 \mathrm{~g} / \mathrm{d})$ or with $100 \mathrm{or} 400 \mathrm{~g} / \mathrm{d}$ of garlic cloves

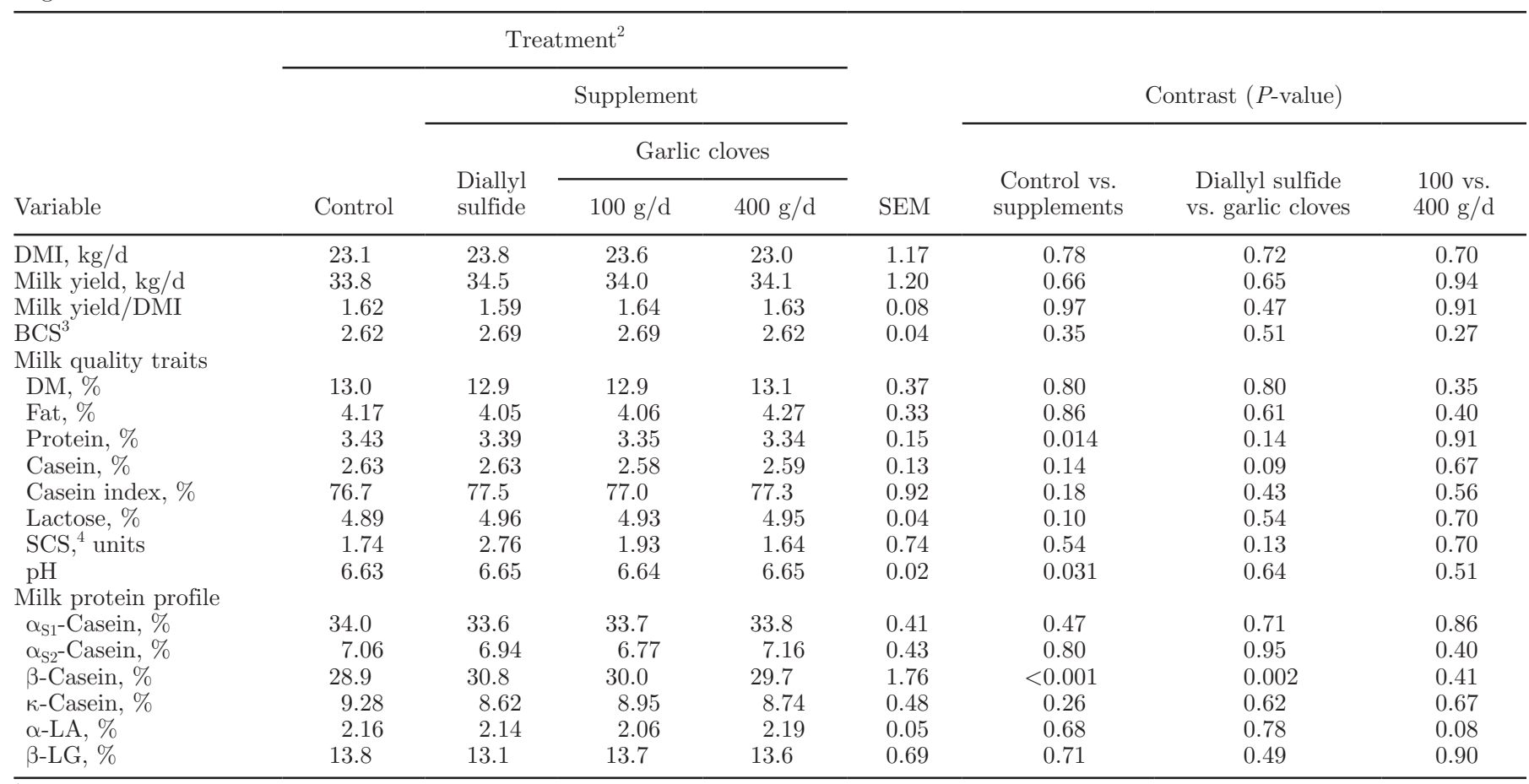

${ }^{1}$ Diallyl sulfide, 0.97 pure (Allyl sulfide, Sigma-Aldrich Chemical, Milan, Italy).

${ }^{2} \mathrm{n}=16$ (4 periods $\times 4$ cows $)$.

${ }^{3} \mathrm{BCS}$ on $1-5$ scale.

${ }^{4} \mathrm{SCS}=3+\ln _{2}\left(\mathrm{SCC} \times 10^{-5}\right)$.

The shear force and corresponding shear work (the work done to cut the sample from the starting point to maximum shear force) were measured using an LS5 dynamometer (Lloyd Instruments Ltd., Bognor Regis, UK) equipped with a Warner-Bratzler probe, 500-N load cell, and crosshead speed of $2 \mathrm{~mm} / \mathrm{s}$, as reported by Segato et al. (2007).

\section{Statistical Analysis}

All data were averaged by period and cow (15 df) and analyzed according to a model of response for a classic $4 \times 4$ Latin square design using SAS PROC MIXED (SAS Institute, 2007):

$$
\mathrm{y}_{\mathrm{ijkl}}=\mu+\mathrm{T}_{\mathrm{i}}+\mathrm{P}_{\mathrm{j}}+\mathrm{C}_{\mathrm{k}}+e_{\mathrm{ijk} \mathrm{l}},
$$

where $y_{\mathrm{ijkl}}$ is the observed trait; $\mu$ is the overall mean; $\mathrm{T}_{\mathrm{i}}$ is the fixed effect of the feeding treatment $(\mathrm{i}=$ $1, \ldots, 4) ; P_{j}$ is the random effect of period $(j=1, \ldots, 4)$; $\mathrm{C}_{\mathrm{k}}$ is the random effect of cow $(\mathrm{k}=1, \ldots, 4)$; and $e_{\mathrm{ijkl}}$ is the residual error term $\sim N\left(0, \sigma_{e}^{2}\right)(6 \mathrm{df})$, where $\sigma^{2}$ is the residual variance. The model used for statistical analysis of milk quality traits and milk sensory traits also included SCS as a covariate. Orthogonal contrasts were run to test the significance of the treatment (control vs. treated samples), the type of supplement (diallyl sulfide vs. fresh garlic), and the garlic dose (100 vs. $400 \mathrm{~g} / \mathrm{d}$ of fresh garlic cloves). Differences were considered statistically significant at $P<0.05$.

\section{RESULTS}

Dietary treatment had no influence on DMI (23.4 $\mathrm{kg} / \mathrm{d})$, milk yield $(34.1 \mathrm{~kg} / \mathrm{d})$, or milk yield $/ \mathrm{DMI}$ ratio (1.62 kg of milk/kg of DMI; Table 2), and had a weak or null influence on milk quality traits compared with controls, with the exception of milk protein content $(P=0.011)$ and $\mathrm{pH}(P=0.033)$, which were slightly lower, and $\beta$-casein, which was higher $(P<0.001)$. The proportion of $\beta$-casein exhibited a greater increase with diallyl sulfide than with garlic cloves $(P=0.002)$.

Rennet coagulation time (both RCT and $\mathrm{RCT}_{\mathrm{eq}}$ ) was very long, averaging $28 \mathrm{~min}$. The $32.5 \%$ of milk samples coagulating after $30 \mathrm{~min}$ were considered noncoagulating samples and therefore had no $\mathrm{a}_{30}$ values. The $\mathrm{CF}_{\mathrm{t}}$ modeling was not affected by these limitations and all parameters were obtained for all samples. However, the treatments did not influence any of the traditional MCP traits or curd firming equation parameters (Table 
Table 3. Milk coagulation properties $(\mathrm{MCP})$, curd firming model parameters $\left(\mathrm{CF}_{\mathrm{t}}\right)$, cheese yields, and nutrient recoveries of cows fed TMR supplemented or not with diallyl sulfide ${ }^{1}(2 \mathrm{~g} / \mathrm{d})$ or with 100 or $400 \mathrm{~g} / \mathrm{d}$ of garlic cloves

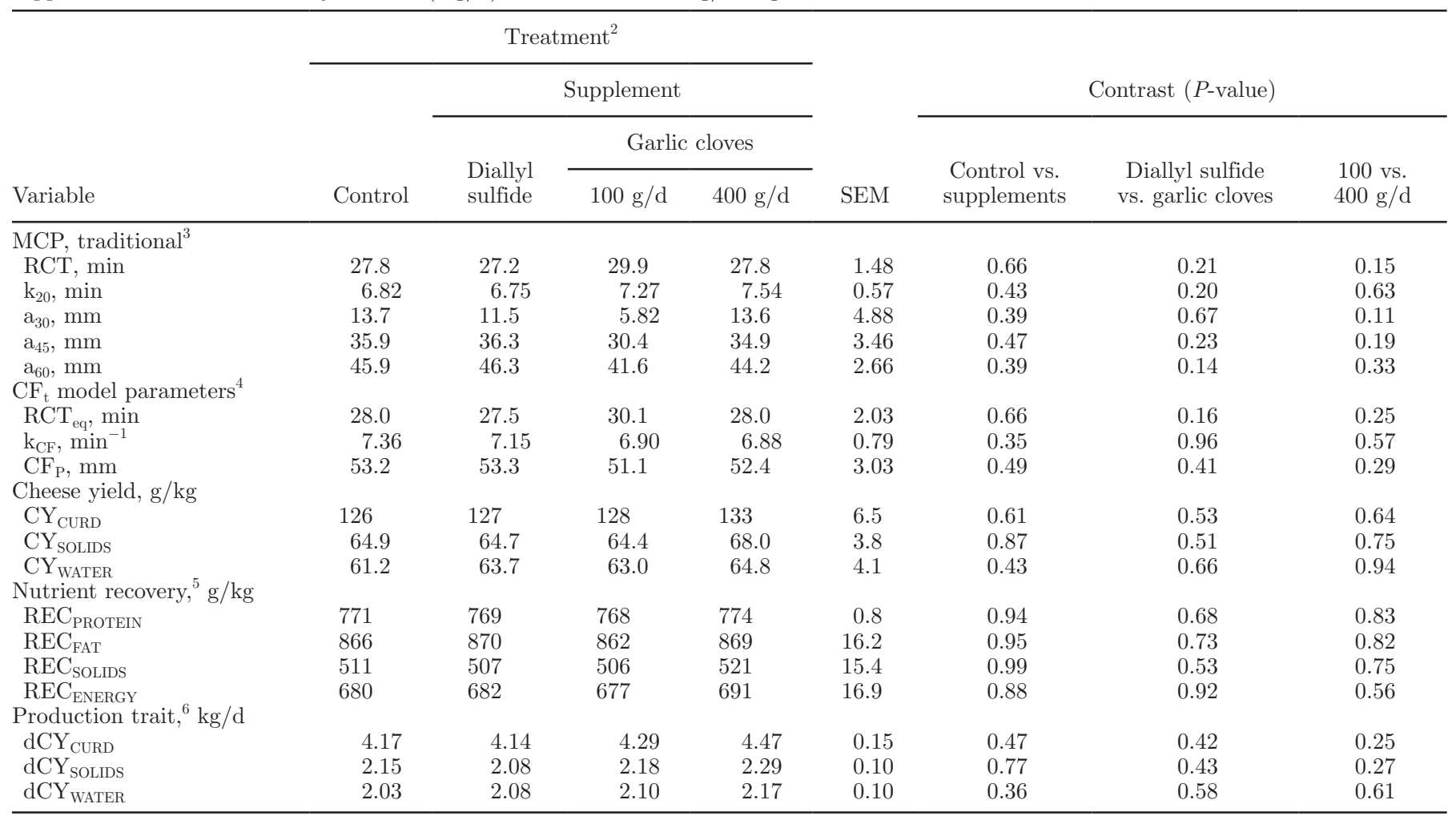

${ }^{1}$ Diallyl sulfide, 0.97 pure (Allyl sulfide, Sigma-Aldrich Chemical, Milan, Italy).

${ }^{2} \mathrm{n}=16$ (4 periods $\times 4$ cows).

${ }^{3} \mathrm{RCT}=$ rennet coagulation time, $\mathrm{k}_{20}=$ curd firming time; $\mathrm{a}_{30}, \mathrm{a}_{45}$, or $\mathrm{a}_{60}=$ curd firmness after 30,45 , or 60 min from rennet addition, respectively.

${ }^{4} \mathrm{RCT}_{\mathrm{eq}}=$ rennet coagulation time, $\mathrm{k}_{\mathrm{CF}}=$ curd-firming rate constant, $\mathrm{CF}_{\mathrm{P}}=$ asymptotical potential value of $\mathrm{CF}$ at an infinite time $($ Bittante, 2011).

${ }^{5} \mathrm{REC}=$ recovery of milk protein, fat, solids, and energy in the curd.

${ }^{6} \mathrm{dCY}=$ daily cheese yields of curd, solids, and retained water $(\mathrm{CY} \times$ daily milk yield $)$.

3). Similarly, dietary treatment had no influence on curd and solid cheese yields; retained water; recoveries of protein, fat, solids, and energy; daily production of curd and cheese solids; and daily retained water.

The treatments increased the garlic-like aroma $(P<$ $0.001)$ and the garlic-like flavor $(P<0.001)$ in milk compared with controls but not the other sensory traits (Table 4). However, the type of supplement and the dose of garlic cloves affected milk sensory attributes. Perception of all the aroma and flavor traits, but not the taste traits, was significantly lower with diallyl sulfide than with garlic. Intensity of overall aroma $(P$ $<0.001)$, garlic-like aroma $(P<0.001)$, saltiness $(P=$ $0.041)$, and garlic-like flavor $(P<0.001)$ were notably greater with the $400 \mathrm{~g} / \mathrm{d}$ dose of garlic cloves than with the lower dose.

The treatments increased the garlic-like aroma $(P<$ $0.001)$, saltiness $(P=0.004)$, intensity of overall flavor $(P=0.009)$, and garlic-like flavor $(P<0.001)$ in the cheeses, and lowered the $\mathrm{pH}(P=0.007)$ and the shear work $(P=0.045)$. Diallyl sulfide increased the fruit-like aroma $(P=0.031)$, and $\mathrm{a}^{*}(P<0.001)$ and $\mathrm{b}^{*}(P<$ $0.001)$ color traits, but lowered the garlic-like aroma $(P<0.001)$, garlic-like flavor $(P<0.001)$, $\mathrm{pH}(P=$ $0.022)$, shear force $(P=0.032)$, and shear work $(P<$ $0.001)$ compared with garlic cloves. The highest dose of garlic cloves increased the intensity of overall aroma $(P$ $<0.001)$, garlic-like aroma $(P<0.001)$, sourness $(P=$ $0.030)$, and garlic-like flavor $(P<0.001)$, but lowered the $\mathrm{L}^{*}(P<0.001)$, shear force $(P<0.001)$, and shear work $(P=0.003)$ compared with the lowest garlic dose.

When the individual scores for garlic-like aroma (Figure $1 ; \mathrm{R}^{2}=0.874$ ) and garlic-like flavor (Figure $2 ; \mathrm{R}^{2}$ $=0.796$ ) in milk and cheese were regressed, we found strong relationships with exponential coefficients less than unity. Furthermore, the garlic-like flavor of milk was positively correlated with the sour $(\mathrm{r}=0.726)$ and bitter tastes $(r=0.685)$ of the cheese derived from it. 
Table 4. Sensory attributes of raw milk and cheese and rheological analysis of ripened cheese of cows fed TMR supplemented or not with diallyl sulfide $^{1}(2 \mathrm{~g} / \mathrm{d})$ or with 100 or $400 \mathrm{~g} / \mathrm{d}$ of garlic peeled cloves

\begin{tabular}{|c|c|c|c|c|c|c|c|c|}
\hline \multirow[b]{3}{*}{ Sample and attribute } & \multicolumn{4}{|c|}{ Treatment $^{2}$} & \multirow[b]{3}{*}{ SEM } & \multirow{2}{*}{\multicolumn{3}{|c|}{ Contrast ( $P$-value $)$}} \\
\hline & \multirow[b]{2}{*}{ Control } & \multicolumn{3}{|c|}{ Supplement } & & & & \\
\hline & & $\begin{array}{l}\text { Diallyl } \\
\text { sulfide }\end{array}$ & $100 \mathrm{~g} / \mathrm{d}$ & $400 \mathrm{~g} / \mathrm{d}$ & & $\begin{array}{l}\text { Control vs. } \\
\text { supplements }\end{array}$ & $\begin{array}{l}\text { Diallyl sulfide } \\
\text { vs. garlic cloves }\end{array}$ & $\begin{array}{l}100 \mathrm{vs} . \\
400 \mathrm{~g} / \mathrm{c}\end{array}$ \\
\hline \multicolumn{9}{|l|}{ Milk } \\
\hline Garlic-like & 1.24 & 1.44 & 1.38 & 4.65 & 0.23 & $<0.001$ & $<0.001$ & $<0.001$ \\
\hline \multicolumn{9}{|l|}{ Taste } \\
\hline Sweetness & 5.10 & 4.94 & 4.98 & 4.52 & 0.24 & 0.38 & 0.52 & 0.19 \\
\hline Saltiness & 2.63 & 2.44 & 2.44 & 2.83 & 0.13 & 0.69 & 0.22 & 0.041 \\
\hline Bitterness & 1.87 & 1.91 & 1.99 & 2.36 & 0.16 & 0.25 & 0.16 & 0.10 \\
\hline \multicolumn{9}{|l|}{ Flavor } \\
\hline Overall intensity & 4.69 & 4.63 & 5.04 & 5.39 & 0.23 & 0.97 & 0.033 & 0.28 \\
\hline Overall intensity & 3.96 & 4.20 & 3.66 & 4.53 & 0.16 & 0.37 & 0.62 & $<0.001$ \\
\hline Grass-like & 3.37 & 3.48 & 3.11 & 3.32 & 0.13 & 0.63 & 0.09 & 0.24 \\
\hline Fruit-like & 2.77 & 3.07 & 2.73 & 2.68 & 0.14 & 0.71 & 0.031 & 0.78 \\
\hline Garlic-like & 1.27 & 1.12 & 1.50 & 2.89 & 0.14 & $<0.001$ & $<0.001$ & $<0.001$ \\
\hline \multicolumn{9}{|l|}{ Taste } \\
\hline Sweetness & 3.23 & 3.46 & 3.05 & 3.25 & 0.14 & 0.89 & 0.08 & 0.33 \\
\hline Saltiness & 3.30 & 3.48 & 3.84 & 3.61 & 0.14 & 0.044 & 0.18 & 0.26 \\
\hline Sourness & 2.45 & 2.48 & 2.57 & 3.11 & 0.17 & 0.17 & 0.09 & 0.030 \\
\hline Bitterness & 2.14 & 1.89 & 2.09 & 2.52 & 0.19 & 0.91 & 0.09 & 0.12 \\
\hline \multicolumn{9}{|l|}{ Flavor } \\
\hline Overall intensity & 4.23 & 4.80 & 4.61 & 5.12 & 0.20 & 0.009 & 0.80 & 0.07 \\
\hline Garlic-like & 1.73 & 1.27 & 2.59 & 4.50 & 0.24 & $<0.001$ & $<0.001$ & $<0.001$ \\
\hline $\mathrm{pH}$ & 5.33 & 5.21 & 5.30 & 5.27 & 0.02 & 0.007 & 0.02 & 0.31 \\
\hline \multicolumn{9}{|l|}{ Color $^{3}$} \\
\hline
\end{tabular}

${ }^{1}$ Diallyl sulfide, 0.97 pure (Allyl sulfide, Sigma-Aldrich Chemical, Milan, Italy).

${ }^{2} \mathrm{n}=16(4$ periods $\times 4$ cows $)$.

${ }^{3}$ CIElab $=\mathrm{L}^{*}=$ reflection index; $\mathrm{a}^{*}=$ green-red index; $\mathrm{b}^{*}=$ blue-yellow index .

${ }^{4}$ Maximum force required to cut the sample.

${ }^{5}$ Work done to cut the sample.

\section{DISCUSSION}

Interest in the use of bioactive plants or plant metabolites as an alternative to chemical substances to mitigate methane emission has greatly increased in recent decades (Patra and Saxena, 2010). The use of garlic as a feed additive has been advocated due to its positive effects on rumen fermentation, digestive processes, and metabolic, anti-inflammatory, and immunestimulant activities, although the major interest is in its antimethanogenic properties (Kamra et al., 2012). Additives may be in the form of fresh cloves, extracts, oil, or powder, or in the form of organosulfur metabolites derived from garlic cloves, such as allicin, diallyl sulfide, diallyl disulfide, and allyl mercaptan, either singly or in combination (Calsamiglia et al., 2007). These metabolites are produced from S-alk(en)yl-Lcysteine sulfoxides (allicin being the largest contributor) by allinase and other enzymes when the garlic cells are broken down. The S-alk(en)yl-L-cysteine sulfoxide content of garlic fresh by weight is 0.53 to $1.3 \%$ (Patra and Saxena, 2010).

\section{Garlic and DMI, Milk Yield, and Milk Quality}

Different forms and doses of garlic have been found to have little or no influence on the DMI of sheep (Patra and Saxena, 2010; Klevenhusen et al., 2011), lactating 


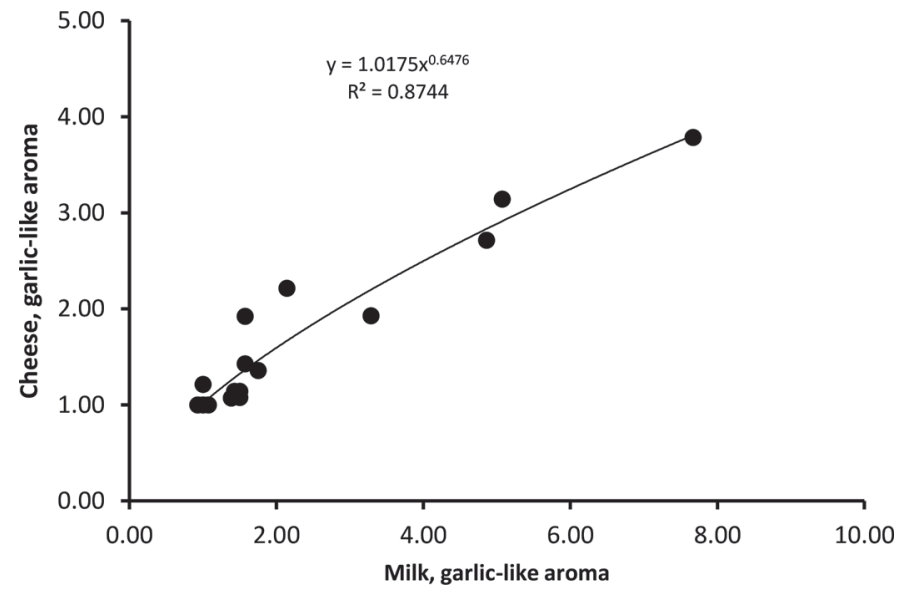

Figure 1. Relationship between milk and ripened cheese garlic-like aroma $(P<0.01)$ of cows fed TMR supplemented or not with $2 \mathrm{~g} / \mathrm{d}$ of diallyl sulfide (Sigma-Aldrich Chemical, Milan, Italy) or with 100 or $400 \mathrm{~g} / \mathrm{d}$ of garlic cloves.

cows (Oh et al., 2013; Blanch et al., 2016; Prayitno et al., 2016), and beef cattle (Staerfl et al., 2012). Patra and Saxena (2010) reported that the DMI of sheep decreased after the addition of $10 \mathrm{~g} / \mathrm{kg}$ DM of fresh garlic cloves, but the effect was transient and no effects were observed after adaptation. Nolte and Provenza (1992) observed that garlic and onions influenced the feed preferences of lambs, although the effect was temporary. Garlic oil and garlic extracts were found to have a small influence on milk yield, milk composition, and feed efficiency (Yang et al., 2007; Oh et al., 2013; Blanch et al., 2016). In the current study, the various treatments had no influence on DMI, milk yield, the milk yield/DMI ratio, or milk composition. Garlic cloves and diallyl sul-

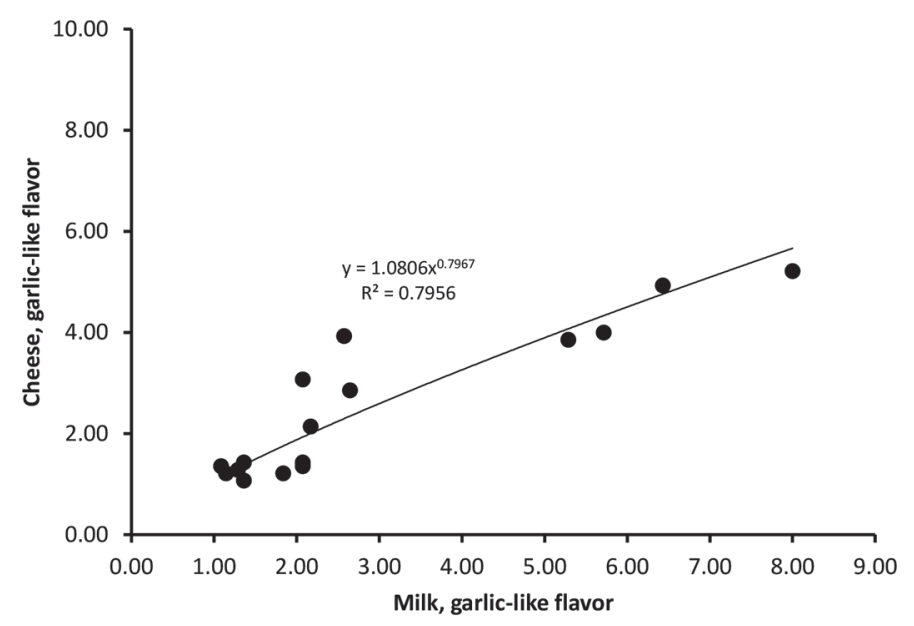

Figure 2. Relationship between milk and ripened cheese garlic-like flavor of cows fed TMR supplemented or not with $2 \mathrm{~g} / \mathrm{d}$ of diallyl sulfide (Sigma-Aldrich Chemical, Milan, Italy) or with 100 or $400 \mathrm{~g} / \mathrm{d}$ of garlic cloves. fide supplements both reduced the milk protein content $(\mathrm{N} \times 6.25)$ by about $2 \%$ compared with controls, but although the various protein fractions were lowered, the proportion of $\beta$-casein increased. Such alterations can, at least partially, be explained by the possible influences that garlic can exert on $\mathrm{N}$ metabolism at ruminal level (Calsamiglia et al., 2007). We suggest, therefore, that the use of garlic at a dose of up to approximately $17.4 \mathrm{~g} / \mathrm{kg}$ of DM would have little or no influence on nutrient utilization, milk yield, or composition.

\section{Cheese-Making Quality of the Milk}

The various garlic treatments had no influence on the MCP evaluated by traditional procedures, although this result is of limited value due to the high incidence of milk samples coagulating later than 30 min after rennet addition, as is frequently observed with HolsteinFriesian cows (Bittante et al., 2012; Stocco et al., 2017). The $\mathrm{CF}_{\mathrm{t}}$ modeling equation parameters, on the other hand, are not affected by the length of $\mathrm{RCT}_{\mathrm{eq}}$ (Stocco et al., 2015), although, also in this case, dietary treatment had almost no effect. The cheese yields and milk nutrient recoveries we obtained in cheese were close to expectations for Holstein cows (Stocco et al., 2018). Similarly, we found the treatments to have no effect on cheese yield traits or on the recoveries of milk protein, fat, solids, and energy in the curd. The absence of any effect of garlic cloves on these traits is consistent with the small variations we observed in the nutritional composition of the milk, particularly in the milk protein profile. To our knowledge, this has not been previously reported in the literature.

\section{Sensory Characteristics of Milk and Cheese}

The sensory qualities of dairy products, and flavor in particular, are known to have a strong influence on consumer acceptability and preferences and market prices (Bittante et al., 2011a,b; Endrizzi et al., 2013). Flavor is a complex trait, composed principally of the sensations of aroma and taste (McSweeney et al., 1997). Milk and cheese flavors are influenced by a variety of volatile and nonvolatile substances (Drake, 2007; Bergamaschi et al., 2015), and as some of these are sulfur compounds (Sreekumar et al., 2009), the enrichment of milk and cheese with undesired flavors is of concern. In fact, many milk and cheese factories do not accept milk produced from cows fed garlic because of off-flavors. Surprisingly, we found no mention of this shortcoming in papers reporting on the addition of garlic or garlic compounds to the feed of dairy cows. However, the presence of odorous metabolites in the cheese is not necessarily a defect, as many traditional cheeses con- 
taining garlic are produced in many parts of the world (Park, 1990; Regu et al., 2016).

A review of the scientific literature reveals a lack of information on the influence of garlic on the flavor of milk. In part, this is due to the difficulties of analyzing sulfur compounds, because of their volatility, sensitivity to oxidation and heat, and presence at very low concentrations (Sreekumar et al., 2009). The recent development of model cheese-making procedures has made it possible to carry out experiments on a large number of individual samples (Cipolat-Gotet et al., 2013), and offers new research opportunities in this field as it is now easier to study the influence of different feeding treatments on milk and cheese characteristics.

In our experiment, we found that garlic, particularly at high doses, influenced olfactory intensity and garliclike aromatic notes in both milk and cheese. However, the sensory attributes of milk and cheese from cows fed supplements of diallyl sulfide or garlic cloves at the lowest dosage were often no different than those of controls. It should be borne in mind that sulfur compounds, including diallyl sulfide, occur naturally in milk and cheese, conferring garlic flavor, and their concentrations increase with the aging of the cheeses to impart several typical aromatic notes (McGorrin, 2011). These sulfur compounds mainly arise from catabolism of L-methionine by bacteria and yeasts, but L-cysteine probably has a greater role in the release of volatile sulfur compounds, imparting garlic-like flavor in cheese (Sutherland et al., 2003).

Garlic is considered to be a taste and flavor enhancer because of its high concentrations of organic sulfur compounds. In our research, $400 \mathrm{~g} / \mathrm{d}$ of garlic cloves increased the salty taste of milk, the sourness of cheese, and the flavor intensity of both milk and cheese. Some garlic compounds, such as the $\gamma$-glutamyl derivatives of S-substituted cysteines found in garlic and in other plants of the Allium genus, may be responsible for these responses (Speranza and Morelli, 2012).

The garlic-like aroma and garlic-like flavor of the milk had close exponential relationships with the characteristics of the cheese derived from it. The intensity of these perceptions apparently decreased from the milk to the cheese with an exponential coefficient $<1$ (Figures 1 and 2). Sensorial perceptions are mediated by other compounds that are present in milk and also in the cheese but in much greater amounts. The greater aromatic and flavor complexity in cheese may mask the olfactory notes of garlic and diallyl sulfide, and therefore suppress the effect of the garlic-like aroma and flavor (Speranza and Morelli, 2012). It should also be borne in mind that olfactory and flavor responses to sulfur molecules are generally nonlinear, as perception differs at low concentrations and at higher concentra- tions, thereby altering the perception of garlic (McGorrin, 2011).

\section{Chemical and Physical Characteristics of Milk and Cheese}

The properties of the sulfur molecules in garlic and their effect on microbial activity during cheese ripening may also be responsible for the observed alterations in the $\mathrm{pH}$, color, shear force, and shear work of the cheese. Both diallyl sulfide and garlic at the highest dose reduced the shear force and shear work of the cheese compared with controls. This is consistent with results obtained by Regu et al. (2016) on cheese matrices with added garlic, and with results on other protein matrices obtained by Kim et al. (2009). Garlic compounds (polyphenols, such as flavonoids and sulfur-containing compounds) exert a strong antioxidant action on protein bonds, and intermolecular disulfide bridges may play a role in the protein strength of meat via oxidation of protein thiol (Wu et al., 2011). Although we did not look at the redox thiol/disulfide formation of cheese proteins in relation to the lowering of the rheological parameters, we might speculate that the samples with garlic at the higher dose and diallyl sulfide may have limited protein thiol oxidation and the resulting disulfide formation in the cheese.

The results suggest that garlic at a high dose and diallyl sulfide affect cheese texture and limit the formation of disulfide bridges by reducing the cohesiveness of the protein network and the weakened cheese structure. The level of $\mathrm{pH}$ also seems to play a role in cheese texture. Lebecque et al. (2001) assert that "as the $\mathrm{pH}$ of cheese curds decreases, there is a loss of colloidal calcium phosphate from casein submicelles with a progressive dissociation of submicelles into smaller casein aggregates." In addition, with the breakdown of casein micelles, the protein surface is more exposed to the action of proteases, and the enzyme-substrate interaction is enhanced, leading to a greater proteolytic effect (Upreti et al., 2006). Therefore, the low rheological values detected in the samples supplemented with $400 \mathrm{~g} / \mathrm{d}$ of garlic cloves and diallyl sulfide may also be due to the effect of $\mathrm{pH}$, because these cheeses had lower $\mathrm{pH}$ values than the other samples.

\section{CONCLUSIONS}

We found that the use of garlic or diallyl sulfide in the cow has very little influence on DMI, milk yield or quality, cheese-making characteristics, nutrient recoveries, and yields of cheese. However, garlic cloves at a dose of $400 \mathrm{~g} / \mathrm{d}$ had a strong influence on the sensory characteristics of milk and cheese. Some rheological 
characteristics of the cheese, $\mathrm{pH}$, color, and texture appeared to be influenced by the administration of diallyl sulfide and garlic cloves. The current paper provided evidence that when garlic or garlic compounds are used to reduce enteric methane emissions, the sensory and rheological characteristics of milk and cheese are affected. However, the garlic-like aroma and garlic-like flavor of milk and cheese are described by exponential relationships $<1.0$, meaning that the increased sensory perception of garlic in milk is only partially reflected in cheese aroma and flavor.

\section{ACKNOWLEDGMENTS}

This study was supported by the University of Padua as part of the "Progetto di Ateneo" (CPDA155250/15), and the ex 60\% (DOR1758092/17 and DOR1770032/17) projects. The authors greatly appreciate the technical assistance of staff of the laboratory and the experimental farm.

\section{REFERENCES}

Ali, A. K. A., and G. E. Shook. 1980. An optimum transformation for somatic cell concentration in milk. J. Dairy Sci. 63:487-490.

AOAC International. 2003. Official Methods of Analysis. 17th ed. 2nd rev. AOAC International, Gaithersburg, MD.

Bàrcenas, P., F. J. P. Elortondo, M. Albisu, J. Mège, L. Bivar Roseiro, M. T. Scintu, P. Torre, S. Loygorri, and P. Lavanchy. 2007. An international ring trial for the sensory evaluation of raw ewes' milk cheese texture. Int. Dairy J. 17:1139-1147.

Bergamaschi, M., E. Aprea, E. Betta, F. Biasioli, C. Cipolat-Gotet, A. Cecchinato, and G. Bittante. 2015. Effects of dairy system, herd within dairy system, and individual cow characteristics on the volatile organic compound profile of ripened cheeses. J. Dairy Sci. 98:2183-2196.

Bittante, G. 2011. Modelling rennet coagulation time and curd firmness of milk. J. Dairy Sci. 94:5821-5832.

Bittante, G., A. Cecchinato, N. Colona, M. Penasa, F. Tiezzi, and M. De Marchi. 2011a. Factors affecting the incidence of first-quality wheels of Trentingrana cheese. J. Dairy Sci. 94:3700-3707.

Bittante, G., N. Cologna, A. Cecchinato, M. De Marchi, M. Penasa, F. Tiezzi, I. Endrizzi, and F. Gasperi. 2011b. Monitoring of sensory attributes used in the quality payment system of Trentingrana cheese. J. Dairy Sci. 94:5699-5709.

Bittante, G., M. Penasa, and A. Cecchinato. 2012. Invited review: Genetics and modeling of milk coagulation properties. J. Dairy Sci. 95:6843-6870.

Blanch, M., M. D. Carro, M. J. Ranilla, A. Viso, M. Vazquez-Anon, and A. Bach. 2016. Influence of a mixture of cinnamaldehyde and garlic oil on rumen fermentation, feeding behaviour and performance of lactating dairy cows. Anim. Feed Sci. Technol. 219:313323.

Busquet, M., S. Calsamiglia, A. Ferret, M. D. Carro, and C. Kamel. 2005. Effect of garlic oil and four of its compounds on rumen microbial fermentation. J. Dairy Sci. 88:4393-4404.

Calsamiglia, S., M. Busquet, P. W. Cardazo, L. Castillejos, and A. Ferret. 2007. Invited review: Essential oils as modifiers of rumen microbial fermentation. J. Dairy Sci. 90:2580-2595.

Cattani, M., R. Mantovani, S. Schiavon, G. Bittante, and L. Bailoni. 2014. Recovery of n-3 polyunsaturated fatty acids and conjugated linoleic acids in ripened cheese obtained from milk of cows fed different levels of extruded flaxseed. J. Dairy Sci. 97:123-135.
Cipolat-Gotet, C., A. Cecchinato, M. De Marchi, M. Penasa, and G. Bittante. 2013. Factors affecting variation in different measures of cheese yield and milk nutrient recovery from an individual model cheese-manufacturing process. J. Dairy Sci. 96:7952-7965.

CIE (Commission Internationale de L'Eclairage). 1986. Colorimetry. 2nd ed. Central Bureau of the Commission Internationale de L'Eclairage, Vienna, Austria.

Drake, M. A. 2007. Invited review: Sensory analysis of dairy foods. J. Dairy Sci. 90:4925-4937.

Edmonson, A. J., I. J. Lean, L. D. Weaver, T. Farver, and G. Webster 1989. A body condition scoring chart for Holstein dairy cows. J. Dairy Sci. 72:68-78.

Endrizzi, I., E. Aprea, F. Biasioli, M. L. Corollaro, M. L. Demattè, M. Penasa, G. Bittante, and F. Gasperi. 2013. Implementing sensory analysis principles in the quality control of PDO products: A critical evaluation of a real-world case study. J. Sens. Stud. 28:14-24.

Hristov, A. N., J. Oh, J. L. Firkins, J. Dijkstra, E. Kebreab, G. Waghorn, H. P. S. Makkar, A. T. Adesogan, W. Yang, C. Lee, P. J. Gerber, B. Henderson, and J. M. Tricarico. 2013a. Mitigation of methane and nitrous oxide emissions from animal operations: I. A review of enteric methane mitigation options. J. Anim. Sci. 91:5045-5069

Hristov, A. N., J. Oh, C. Lee, R. Meinen, F. Montes, T. Ott, J. Firkins, C. A. Rotz, C. J. Dell, A. Adesogan, W. Yang, J. Tricarico, E. Kebreab, G. Waghorn, J. Dijkstra, and S. Oosting. 2013b. Mitigation of greenhouse gas emissions in livestock production-A review of technical options for non- $\mathrm{CO}_{2}$ emissions. FAO, Rome, Italy. Report 177. http://www.fao.org/docrep/018/i3288e/i3288e.pdf.

ISO. 1985. Sensory analysis-Methodology-General guidance. ISO \#6658. International Organization for Standardization (ISO), Geneva, Switzerland.

ISO. 1988. Sensory analysis-General guidance for the design of test rooms. ISO \#8589. International Organization for Standardization (ISO), Geneva, Switzerland.

Kamra, D. N., N. Agarwal, P. C. Sakthivel, and L. C. Chaundhary. 2012. Garlic as rumen modifier for eco-friendly and economic livestock production. J. Appl. Anim. Res. 40:90-96.

Kim, Y. J., S. K. Jin, and H. S. Yang. 2009. Effect of dietary garlic bulb and husk on the physicochemical properties of chicken meat. Poult. Sci. 88:398-405.

Klevenhusen, F., J. O. Zeitza, S. Duvalb, M. Kreuzera, and C. R. Soliva. 2011. Garlic oil and its principal component diallyl disulfide fail to mitigate methane, but improve digestibility in sheep. Anim. Feed Sci. Technol. 166-167:356-363.

Lavanchy, P., J. Mege, F. J. Pérez Elortondo, L. Bivar Roseiro, M. F. Scintu, and P. Torre. 1999. A guide to the sensory evaluation of the texture of hard and semi-hard ewes' milk cheese. Office for Official Publications of the European Communities, Luxembourg.

Lebecque, A., A. Laguet, M. F. Devaux, and E. Dufour. 2001. Delineation of the texture of Salers cheese by sensory analysis and physical methods. Lait 81:609-623.

Macheboeuf, D., B. Lassalas, M. J. Ranilla, M. D. Carro, and D. P. Morgavi. 2006. Dose response effect of diallyl disulfide on ruminal fermentation and methane production in vitro. Reprod. Nutr. Dev. 46:S103.

Maurmayr, A., A. Cecchinato, L. Grigoletto, and G. Bittante. 2013. Detection and quantification of $\alpha \mathrm{S} 1-, \alpha \mathrm{S} 2-, \beta-, \kappa$-casein $\alpha$-lactalbumin, $\beta$-lactoglobulin and lactoferrin in bovine milk by reverse-phase high-performance liquid chromatography. Agric. Conspec. Sci. 78:201-205.

McGorrin, R. J. 2011. The significance of volatile sulfur compound in food flavors: An overview. Chapter 1, pages 3-31 in Volatile Sulfur Compounds in Food. Vol. 1068, M. C. Qian, X. Fan, and K. Mahattanatawee, ed. ACS Symposium Series, American Chemical Society, Washington, DC.

McMahon, D. J., and R. J. Brown. 1982. Evaluation of Formagraph for comparing rennet solutions. J. Dairy Sci. 65:1639-1642.

McSweeney, P. L. H., H. E. Nursten, and G. Urbach. 1997. Flavours and off-flavours in milk and dairy products. Pages 403-468 in Advanced Dairy Chemistry. Vol. 3. P. F. Fox, ed. Springer, Boston, MA. 
Meilgaard, M., G. V. Civille, and B. T. Carr. 1991. Sensory Evaluation Techniques. 2nd ed. CRC Press, Taylor and Francis Group, New York, NY.

Mertens, D. R., M. Allen, J. Carmany, J. Clegg, A. Davidowicz, M. Drouches, K. Frank, D. Gambin, M. Garkie, B. Gildemeister, D. Jeffress, C. S. Jeon, D. Jones, D. Kaplan, G. N. Kim, S. Kobata, D. Main, X. Moua, B. Paul, J. Robertson, D. Taysom, N. Thiex, J. Williams, and M. Wolf. 2002. Gravimetric determination of amylase-treated neutral detergent fiber in feeds with refluxing in beakers or crucibles: Collaborative study. J. AOAC Int. 85:1217-1240.

Negussie, E., Y. de Haas, F. Dehareng, R. J. Dewhurst, J. Dijkstra, N. Gengler, D. P. Morgavi, H. Soyeurt, S. van Gastelen, T. Yanand, and F. Biscarini. 2017. Invited review: Large-scale indirect measurements for enteric methane emissions in dairy cattle: A review of proxies and their potential for use in management and breeding decisions. J. Dairy Sci. 100:2433-2453.

Nolte, D. L., and F. D. Provenza. 1992. Food preferences in lambs after exposure to flavors in solid foods. Appl. Anim. Behav. Sci. 32:337-347.

NRC. 2001. Nutrient Requirements of Dairy Cattle. 7th rev. ed. Natl. Acad. Sci., Washington, DC.

Oh, J., A. N. Hristov, C. Lee, T. Cassidy, K. Heyler, G. A. Varga, J. Pate, S. Walusimbi, E. Brzezicka, K. Toyokawa, J. Werner, S. S. Donkin, R. Elias, S. Dowd, and D. Bravo. 2013. Immune and production responses of dairy cows to postruminal supplementation with phytonutrients. J. Dairy Sci. 96:7830-7843.

Pagliarini, E., P. Lembo, and M. Bertuccioli. 1991. Recent advancements in sensory analysis of cheese. Ital. J. Food Sci. 3:85-99.

Park, Y. W. 1990. Nutrient profiles of commercial goat milk cheese manufactured in the United States. J. Dairy Sci. 73:3059-3067.

Patra, A. K., and J. Saxena. 2010. A new perspective on the use of plant secondary metabolites to inhibit methanogenesis in the rumen. Phytochemistry 71:1198-1222.

Pinho, O., E. Mendes, M. M. Alves, and I. M. Ferreira. 2004. Chemical, physical, and sensorial characteristics of "Terrincho" ewe cheese: Changes during ripening and intravarietal comparison. J. Dairy Sci. 87:249-257.

Pitesky, M. E., K. R. Stackhause, and F. M. Mitloehner. 2009. Clearing the air: Livestock's contribution to climate change. Adv. Agron. 103:1-40.

Prayitno, C. H., Suwarno, S. Susanto, and A. Jayanegara. 2016. Effect of garlic extract and organic mineral supplementation on feed intake, digestibility and milk yield of lactating dairy cows. Asian J. Anim. Sci. 10:213-218.

Regu, M., Z. Yilma, and E. Seifu. 2016. Effect of garlic (Allium sativum) and ginger (Zingiber officinale) powder on chemical composition and sensory property of Ayib - Ethiopian cottage cheese. Int. Food Res. J. 23:1226-1232.

Reuter, H. D., J. P. Koch, and L. Lawson. 1996. Therapeutic effects and applications of garlic and its preparations. Pages 135-212 in The Science and Therapeutic Application of Allium sativum L. and Related Species. H. P. Koch and L. D. Lawson, ed. Williams and Wilkins, Baltimore, MD.

Robertson, J. B., and P. J. Van Soest. 1981. The detergent system of analysis and its application to human foods. Pages 123-158 in The Analysis of Dietary Fiber in Food. W. P. T. James, O. Theander, ed. Marcel Dekker Inc., New York, NY.

SAS Institute. 2007. SAS User's Guide: Basics. SAS Institute Inc., Cary, NC.

Scheffler, L., Y. Sauermann, G. Zeh, K. Hauf, A. Heinlein, C. Sharapa, and A. Buettner. 2016. Detection of volatile metabolites of garlic in human breast milk. Metabolites 6:18.

Schiavon, S., G. Cesaro, F. Tagliapietra, L. Gallo, and G. Bittante. 2015. Influence of $\mathrm{N}$ shortage and conjugated linoleic acid supple- mentation on some productive, digestive, and metabolic parameters of lactating cows. J. Dairy Sci. 208:86-97.

Segato, S., S. Balzan, C. A. Elia, L. Lignitto, A. Granata, L. Magro, B. Contiero, I. Andrighetto, and E. Novelli. 2007. Effect of period of milk production and ripening on quality traits of Asiago cheese. Ital. J. Anim. Sci. 6:469-471.

Speranza, G., and C. F. Morelli. 2012. $\gamma$-Glutamyl transpeptidasecatalyzed synthesis of naturally occurring flavor enhancers. J. Mol Catal., B Enzym. 84:65-71.

Sreekumar, R., Z. Al Attabi, H. C. Deeth, and M. S. Turner. 2009. Volatile sulfur compounds produced by probiotic bacteria in the presence of cysteine or methionine. Lett. Appl. Microbiol. 48:777-782.

Staerfl, S. M., J. O. Zeitz, M. Kreuzer, and C. R. Soliva. 2012. Methane conversion rate of bulls fattened on grass or maize silage as compared with the IPCC default values, and the long-term methane mitigation efficiency of adding acacia tannin, garlic, maca and lupine. Agric. Ecosyst. Environ. 148:111-120.

Steinfeld, H., P. Gerber, T. D. Wassenaar, V. Castel, and C. de Haan. 2006. Livestock's Long Shadow: Environmental Issues and Options. Food and Agriculture Organization of the United Nations, Rome, Italy.

Stocco, G., C. Cipolat-Gotet, T. Bobbo, A. Cecchinato, and G. Bittante. 2017. Breed of cow and herd productivity affect milk composition and modeling of coagulation, curd firming, and syneresis. J. Dairy Sci. 100:129-145.

Stocco, G., C. Cipolat-Gotet, A. Cecchinato, L. Calamari, and G. Bittante. 2015. Milk skimming heating, acidification, lysozyme, and rennet affect the pattern, repeatability, and predictability of milk coagulation properties and of curd-firming model parameters: A case study of Grana Padano. J. Dairy Sci. 98:5052-5067.

Stocco, G., C. Cipolat-Gotet, V. Gasparotto, A. Cecchinato, and G. Bittante. 2018. Breed of cow and herd productivity affect milk nutrient recovery in curd, and cheese yield, efficiency and daily production. Animal 12:434-444. https://doi.org/10.1017/ S1751731117001471.

Sutherland, C. M., P. A. Henschke, P. Langridge, and M. BarrosLopes. 2003. Subunit and cofactor binding of Saccharomyces cerevisiae sulfite reductase - Towards developing wine yeast with lowered ability to produce hydrogen sulphide. Aust. J. Grape Wine Res. 9:186-193.

Suzzi, G., G. Sacchetti, F. Patrignani, A. Corsetti, R. Tofalo, M. Schirone, G. Fasoli, F. Gardini, G. Perpetuini, and R. Lanciotti. 2015. Influence of pig rennet on fatty acid composition, volatile molecule profile, texture and sensory properties of Pecorino di Farindola cheese. J. Sci. Food Agric. 95:2252-2263.

Upreti, P., L. L. McKay, and L. E. Metzger. 2006. Influence of calcium and phosphorus, lactose, and salt-to-moisture ratio on cheddar cheese quality: Changes in residual sugars and water-soluble organic acids during ripening. J. Dairy Sci. 89:429-443.

van Zijderveld, S. M., J. Dijkstra, H. B. Perdok, J. R. Newbold, and W. J. J. Gerrits. 2011. Dietary inclusion of diallyl disulfide, yucca powder, calcium fumarate, an extruded linseed product, or medium-chain fatty acids does not affect methane production in lactating dairy cows. J. Dairy Sci. 94:3094-3104.

Wu, M. G., Y. L. Xiong, and J. Chen. 2011. Role of disulphide linkages between protein-coated lipid droplets and the protein matrix in the rheological properties of porcine myofibrillar protein-peanut oil emulsion composite gels. Meat Sci. 88:384-390.

Yang, W. Z., C. Benchaar, B. N. Ametaj, A. V. Chaves, M. L. He, and T. A. McAllister. 2007. Effects of garlic and juniper berry essential oils on ruminal fermentation and on the site and extent of digestion in lactating cows. J. Dairy Sci. 90:5671-5681. 